\title{
Representations of Diversity in the Revised New Zealand PictureBook Collection
}

\author{
Nicola Daly \\ Te Hononga School of Curriculum and Pedagogy, University of Waikato, Hamilton, New Zealand
}

\begin{abstract}
Collections of children's literature are used for a range of reasons including preservation, record keeping, and more recently the encouragement of intercultural understanding. Both the significance of learning about other cultures and the importance of children seeing themselves reflected in the books that they read have been discussed extensively. In 2010, the New Zealand PictureBook Collection (NZPBC) was developed in order to create a resource that reflected New Zealand national identity. In 2015 the NZPBC was revised and this article presents a visual and textual analysis of the diversity present in the sixty books nominated through the lens of critical multicultural analysis, using four variables. Findings indicate considerable diversity is present in the collection in terms of representations of ethnicity and family; less so for representations of disability and languages.
\end{abstract}

\section{KEYWORDS}

Picturebooks; diversity; collections

\section{Introduction}

Children's literature collections are used in a number of ways across the world. Some are collected as historical record of books from certain eras, for example, the Dorothy Neal White Collection housed at the National Library of New Zealand Te Puna Matauranga o Aotearoa, which is a collection of over 7,000 English language books published before 1940 and donated to the library by the late and influential children's librarian and Carnegie Fellow, Dorothy Neal White (Friends of the DNWC). Others, such as the International Youth Library (Internationale Judenbibliotek) established in Munich, Germany in 1949, house collections for the purpose of cataloguing and preserving books as artifacts of culture and diversity and supporting research (Internationale Judenbibliotek).

More recently, children's literature collections have been formed with the specific purpose of creating international understanding. For example, the International Children's Digital Library, "Mission" was created with the intention of supporting "the world's children in becoming effective members of the global community-who exhibit tolerance and respect for diverse cultures,

CONTACT Nicola Daly nicolad@waikato.ac.nz Te Hononga School of Curriculum and Pedagogy, University of Waikato, Private Bag 3105, Hamilton 3214, New Zealand.

Published with license by Taylor \& Francis. @ Nicola Daly 
languages and ideas-by making the best in children's literature available online free of charge." Created by an interdisciplinary team at the University of Maryland (USA), this collection currently consists of 4,619 books in fiftyone languages, and is used by people from 228 different countries (International Children's Digital Library Mission, "Library Fast Facts"). Another example of a collection created primarily for intercultural understanding is the European Picture Book Collection (EPBC; Cotton), a collection of twenty picturebooks from twenty European Union countries, which was established in order to develop understanding between members of the European Union. This collection has been developed further to assist in language teaching in European classrooms. Inspired by the EPBC but with a national rather than an international focus, the New Zealand PictureBook Collection, a collection of twenty-two picturebooks reflecting diversity in New Zealand, was selected by a panel of six experienced librarians and teachers over a series of five group discussion sessions in 2010 with the purpose of providing a resource for use in New Zealand classrooms, which reflected the diversity of children in those classrooms (for more detail concerning this process refer to Daly and McKoy).

Children's literature, which represents the stories of minoritized groups, is known as multicultural children's literature. Cai (cited in Johnson 302) says that multicultural literature has a purpose. It is "a group of works used to break the monopoly of the mainstream culture and make the curriculum pluralistic" (Johnson 302). Research shows that representations of diversity in English language children's literature has been limited. The Cooperative Children's Book Center (CCBC) based at the University of Wisconsin, USA, for example, has examined statistics relating to the ethnicity of characters in books received by the library. Disturbingly, their figures show that in 2014 only $11 \%$ of the library's 3,500 books had main characters who were not Caucasian, although this number had increased somewhat from the eight percent in 2013.

But in the field of children's literature, (and in other fields) the term "diversity" is understood to encompass more than just ethnicity. In this article, diversity in a children's picturebook collection, The Revised New Zealand PictureBook Collection (NZPBCII) collated to reflect New Zealand identity, will be considered in terms of ethnicity, family-composition, disabilities, and language diversity. The composition of families in New Zealand, like that in many Western countries, has been changing over the past half century in ways directly influenced by a rise in the number of divorces, a decrease in the number of marriages, a small but steady number of civil unions between same-sex couples, and the younger demographic profile of Māori, ${ }^{1}$ Pasifika, ${ }^{2}$ and Asian communities as compared with the Pākehā ${ }^{3}$ majority (Statistics New Zealand, "Major Ethnic Groups").

${ }^{1}$ Māori are the indigenous people of New Zealand.

${ }^{2}$ Pasifika is an umbrella term used to represent communities in New Zealand from a range of Pacific islands. 
Two studies of picturebooks featuring same-sex parents have been conducted in New Zealand (Hardie; Kelly). In both cases the books examined were not necessarily books published in New Zealand; rather, the authors were interested in finding out the access children had through school and city libraries to picturebooks featuring same-sex parents (Hardie), and the effect on kindergarten children of picturebooks featuring same-sex parents. Hardie found three titles in the fifty-eight libraries surveyed in Wellington and Porirua; whereas, Kelly found that while kindergarten children exposed to picturebooks featuring same-sex parents were open to discussing nontraditional families, teachers were not confident in exploring these issues.

Most recently a study of family representation in the original New Zealand PictureBook Collection (Daly, "Family Composition as Depicted") noted that a range of family structures were evident in the text and illustration of the NZPBC picturebooks, including single parents, blended families, extended families, and nuclear families. However, families of same-sex parents were not represented, nor were families of ethnicities other than Pākehā, Māori, or Pasifika.

The importance of children of diverse abilities being authentically represented in children's literature has been discussed by several authors (e.g., Rieger and McGrail; Beckett et al.; Prater et al.). The visibility of such characters has implications for children with a disability who need to (and have the right to) see themselves as part of stories, whether as the main character, or as part of the context of the story. The visibility of characters with a disability also has implications for developing positive attitudes and awareness among children deemed not to have a disability. Beckett et al. examined the representation of children with disabilities in children's books for five to eleven year olds, and their results showed that while some books still used discriminatory language and negative stereotypes, there were also books featuring some constructive and positive representations of children with disabilities.

Language diversity within picturebooks has perhaps not been as closely examined as the other aspects of diversity previously discussed. Language diversity can take several forms: (1) the use of single words called loanwords (or borrowings) often from a minority language within a dominant language base (Daly, "Kūkupa, Koro and Kai"; "The Narrative Contract"); (2) Parallel language books that feature two languages, either on the same page or separate pages (Naqvi et al.); and (3) books that are published in two or more versions, each version using a different language (Hadaway and Young).

Dual Language Books (DLBs) are not only important in maintaining community languages belonging to immigrant and refugee communities. They also have an important role to play in maintaining indigenous languages (Hadaway

${ }^{3}$ Pākehā is a term used to denote New Zealanders of European descent. 
and Young). Hadaway and Young show how books can increase community awareness of indigenous languages; they reveal attitudes to languages in terms of the order in which languages are presented on pages, the fonts and size of fonts used, and DLBs can also reflect multiple perspectives and authentic voices from an indigenous perspective. The use of a range of languages within children's literature has been the focus of several recent studies often motivated by the pedagogical potential of such resources. Naqvi et al. explain that "DLBs can potentially address the diverse ethnic and linguistic composition of mainstream classrooms by supporting home-language literacy and English literacy development concomitantly" (504). Peterson and Heywood showed that when teachers and principals were invited into classrooms to read DLBs, there was a change in school practices that "better accommodated the language, customs and values of the immigrant families" (cited in Naqvi et al. 505).

In sum, studies of diversity in terms of ethnicity, family, disability, and languages in children's literature, on the whole, show limited diversity is present in children's literature, and this means that young readers are being exposed to an inaccurate representation of their world: one which supports a white, middle class, able bodied, heterosexual, monolingual hegemony. In this study, the sixty books nominated for the NZPBCII are analyzed with a critical multicultural lens. This approach sees multicultural literature as a "vehicle to fight the hegemony of the dominant culture in the publication of children's literature" (Botelho and Rudman 279).

\section{Method}

The sixty picturebooks were nominated to constitute the NZPBCII in an online survey of twenty-five librarians, writers, and teachers throughout New Zealand who were asked to nominate up to five books that they believed reflected New Zealand identity. ${ }^{4}$ The books were located and their content analysed in terms of both text and image with regard to the following four variables, which had been generated from existing literature concerning diversity in children's literature: (1) representations of ethnicity; (2) representations of family; (3) representations of disability; and (4) use of language.

\section{Representations of ethnicity}

The text of the picturebooks was analyzed in light of the use of terms (e.g., Spanish, Māori) or aspects of the story (including setting) denoting the ethnicity of characters. Names were also considered. Text was analysed in

\footnotetext{
${ }^{4}$ The survey participants did give reasons for their nominations, but analysis of this text was not the focus of the analysis for this article.
} 
conjunction with skin tone and facial features (for example moko) evident in the illustrations. Where neither text nor illustration provided conclusive evidence, the category "indeterminate" was used. In many cases, illustrations depicted people with a range of ethnicities, and these books were placed under the category "mixed."

\section{Representations of family}

Both the storyline and the use of words such as family/whänau were examined to determine family groupings. Relational terms such as uncle, aunty, grandma, and Nanny were also used to determine family composition. In addition, the depiction of groups of people in illustrations was also considered.

\section{Representations of disability}

The text was examined for terms relating to disability such as blind or deaf or wheelchair, but storylines were also considered for more subtle indications of disability. Illustrations were also examined for depictions of people with disabilities.

\section{Use of language}

Analysis relating to language was of the text and layout and sometimes also the illustrations in the picturebooks. Following on from previous studies of Māori loanwords in New Zealand English picturebooks (Daly, "Kūkupa, Koro and Kai"; Macdonald and Daly), aspects of the text analyzed included the use of italics and the use of diacritics such as macrons (for the long vowel in te reo Māori). Layout was examined regarding the order of different languages and their placement on the page.

\section{Books}

Sixty books were analyzed in the NZPBII in total. These books ranged in date of publication from 1973 (My Cat likes to Hide in Boxes by Eve Sutton and Lynley Dodd) to 2015 (Mōtiti Blue and the Oil Spill by Debbie McCauley and T. Waaka), with the majority (sixty-five percent) of books nominated having been published in the twenty-first century. 
Table 1. Ethnicity of characters in revised NZPBC.

\begin{tabular}{lccccc}
\hline Māori & Pākeha & Pasifika & Mixed & indeterminate & animals \\
\hline 11 & 10 & 2 & 25 & 5 & 7 \\
\hline
\end{tabular}

\section{Findings and discussion}

\section{Ethnicity}

As previously described, both the text and illustrations were used to identify the ethnicity of characters in the picturebooks nominated. Table 1 shows that the largest proportion of books (25/60) depicted a mix of ethnicities. Two examples of this are books that deliberately include many different ethnicities as part of the story. Sarah Johnson and S. Tulloch's Wooden Arms tells the story of a building that begins life as a meeting house in pre-European New Zealand, and over the years has had many purposes involving many different parts of the community, including an Italian shoemaker, a Hindi dressmaker, and a Samoan dance class. Mere McKaskills' Boil Up by Tracy Duncan (Mere McKaskill's Boil-Up) is about Mere McKaskill inviting all her neighbors of many ethnicities to share in a boil up (a stew consisting of pork bones and greens). While the main character in Lillibutt's Te Araroa Adventure (O'Rourke and Eyley) is a Kunikuni pig travelling from the top of the North Island of New Zealand to the city of Auckland via a trail known as Te Araroa ("the long trail"), the human characters depicted in Pond Eyley's illustrations are both Māori and Pākehā as shown by skin color, context (marae) and language use. A Spanish family is also included, who say to Lillibutt: "Buen Camino, Buen Camino you brave little peregrina" (no page).

Almost equal numbers of books (eleven Māori; ten Pākehā) presented books with either all characters Pākehā, or all Māori. For example, in Robyn Belton's Herbert the Brave Sea Dog and Margaret Mahy and S. Kellogg's The Boy Who Was Followed Home all characters appear to be Pākehā in the illustration, judging by the color of the skin and their facial features. Whereas in Nanny Mihi's Garden (Drewery and Duncan), two grandchildren visit their grandmother (Nanny Mihi) in school holidays across the seasons, and learn all about seasonal vegetables. The names of the characters, the mixing of Māori and English and the illustrations all indicate these characters are Māori in ethnicity. Also, in Melanie Drewery and B. Potter's Matariki a Māori family celebrates Matariki (the Māori new year) with a bonfire on the beach, cooking seasonal kai ("food") and discussing the appearance of Matariki, the star constellation which heralds the Māori new year. The skin color depicted in the illustrations, use of Māori and English, and the particular cultural celebration at the centre of the story, all point to the ethnicity of the characters being Mãori.

Two books depicted characters who were all Pasifika. Both Tane Steals the Show (Nelisi and Hunter) and Papa's Jandals (Moetaua and Potter) have 
Cook Island Māori characters. This is deduced by the nature of the performances illustrated in Tane Steals the Show and the names of characters in Papa's Jandals, and the color of their skin, in conjunction with the names of some items, for example the taro patch. ${ }^{5}$

The high proportion of books (38/60 or sixty-three percent) depicting "people of color" either as the only characters (eleven Māori plus two Pasifika), together with books showing people with a range of skin colors (mixed = twenty-five) is in stark contrast to that in the books in the Cooperative Children's Book Center whose analysis of their 3,500 books showed that only eleven percent of them depicted characters who were not Caucasian.

The fourth most frequent category of book had anthropomorphised characters, for example, Old Huhu (Mewburn and Drsicoll) and Mark and Rowan Somerset's Baa Baa Smart Sheep (Sommerset and Sommerset). Old Huhu is a Huhu grub (a Huhu beetle larvae) who dies and leaves behind a friend $(\mathrm{Hu} \mathrm{Hu}$ Two) to work out what death is and what might have happened to his friend Old Huhu. Baa Baa Smart Sheep is a humorous tale of a sheep that convinces a turkey to eat his poo by labelling them "smarty tablets." In both cases the anthropomorphized characters may be in part due to the fact that the stories deal with taboo subjects of death and bodily excretions (Burke et al.).

\section{Family}

As mentioned earlier, there have been several studies of how the family unit is depicted in New Zealand children's literature. One study was of the family composition represented in the original New Zealand PictureBook Collection (Daly, "Family Composition as Depicted"). In that study, single parent families and blended families, as well as extended families and nuclear families are present, reflecting the reality of diversity in New Zealand family structure (Cook). The special place of grandparents in children's lives is also visible in seven of the fifteen books, and follows similar trends to analyses of English children's literature in which the extended family has growing prominence (Alston). Books featuring same-sex parents were not represented, and this is also the case for the books nominated in this study (see Table 2). However, a similar diversity of family configurations was present in the new nominations analyzed in this article.

Table 2. Family configurations presented in revised NZPBC.

\begin{tabular}{lcccc}
\hline Nuclear & Extended & Single parent & Blended & No families \\
\hline 17 & 15 & 7 & 1 & 20 \\
\hline
\end{tabular}

${ }^{5}$ Taro is a root crop, rather like a potato. It is an important part of the diet of Pacific Island people. 
Seventeen books presented nuclear families consisting of mother and father and a number of children. For example in Cowley and Bishop's The Little Tractor, the "man with the sticky up hair" drove the tractor to his home "there to meet his wife and five handsome children" (no page). And in $A$ Kiwi Night Before Christmas Morrison and Hinde depict in text and illustration a mother, father, and two children. Extended families, including grandparents, were again very frequent; for example, in Melanie Drewery's Nanny Mihi books, grandchildren are visiting their grandmother; and in Moetaua and Potter's Papa's Jandals the family at the center of the story includes grandparents, uncles, and aunties.

Single parents are evident in seven books. The single mother in The Trolley has been discussed elsewhere (Daly, "Family Composition as Depicted"), and there is also a single parent in the The Christmas Caravan (Beck and Belton). In this story a boy and his mother who live in a caravan park enter a Christmas decoration competition but are not visited by the judges because of their location. A blended family is only evident in one story, Dad's Takeaways (Drewery and White), and this is indicated by the use of the name, Ngaere, rather than Mum, in the story.

\section{Disability}

Despite the power of books to break down barriers regarding disabilities (Rieger and McGrail; Beckett et al.; Prater et al.), a minimal amount of representation of disability was found in the New Zealand picturebooks nominated (see Table 3). However, in the two books that deal explicitly with a blind character and a deaf character, this is done in an authentic way (Blaska). In Colour the Stars (McMillan and White) Isaac shows Luke how to recognize colors through senses other than sight. Nowhere in the story text is the word "blind" used, but at the end of the book is an information panel about Guide Dogs for the Blind, and proceeds from the book will go to this cause. The only indications of the fact that Luke is blind is on the first page of the story where Isaac asks Luke "Do you know about colours, Luke?," and later in the story Isaac says to Luke "When I shut my eyes I hear things that I hadn't noticed before. Do you hear like this ... all the time?" Illustrations use strong colors and show Luke and Isaac outdoors doing things together and being active outdoors as you would expect two boys to be. This depiction of Luke's disability is authentic because although his blindness is central to the story, Isaac is shown to respect rather than ridicule it, and to understand the

Table 3. Representation of disability in revised NZPBC.

\begin{tabular}{lccc}
\hline No disability depicted & War wounded & Blindness & Deafness \\
\hline 55 & 3 & 1 & 1 \\
\hline
\end{tabular}


importance of hearing in sight's absence. Language emphasizing Luke's disability is not used, and the friendship between the two boys is depicted as one of mutual respect, each boy having something to offer the other.

The ink painting illustrations in The Birds of Summer (Prebble and Henderson) use only greys, blacks, and white, and this story presents Rewi Marama (who we only know to be deaf because of a line stating this on the second page of the story "The child was deaf" [8]), is an active child who has been sent to live with her recently widowed grandmother near where the godwits spend the summer months. She takes special interest in the birds and helps to rehabilitate a white godwit that is injured. She then eagerly awaits this bird's return after the flock's time in Siberia. Near the end, the text again alludes to her deafness "She could not hear the thundering roar of the ocean ... she could not hear, but she could see" (69). In this story, Rewi Marama's deafness is not central to the story. It is clearly named but aside from this, she is depicted as any other girl would be waiting and anticipating the return of the bird that she helped to rehabilitate.

In one of the three books depicting war wounded, Grandad's Medals (Duncan and Potter), the narrator, a young boy, tells us of his special relationship with his grandad, with whom he goes fishing and flies kites. He describes admiring his grandad's medals and going to the annual Anzac ${ }^{6}$ parade with him. In the double spread of the Anzac parade, the text says "A few of them use walking sticks, and one man is in a wheel chair" (no page), and a returned service man is depicted in a wheelchair in two double page spreads.

\section{Language}

Of the three kinds of dual language picturebooks possible (discussed earlier), only two were evident in the books nominated for the Revised NZPBC: Books using loanwords and Parallel text books. As can be seen in Table 4, the largest number of books used an English text with borrowed words. These borrowings came from Māori in the main. For example, in The Girls in the Kapahaka (Belcher and Tipuna), there are occasions where there is a codeswitch for counting "tahi, rua, toru, wha" (no page), and also borrowed words including piupiu ("skirt"), kuia ("grandmother"), kaiako ("teacher"), koro ("koro"), poi ("taiaha"; "spear"), and whanau ("family"). However, there are also books that include borrowings from other languages such as in the

Table 4. Language use in revised NZPBC.

\begin{tabular}{lcc}
\hline Borrowed words & Single language (English) & Parallel texts \\
\hline 32 & 24 & 4 \\
\hline
\end{tabular}

\footnotetext{
${ }^{6}$ ANZAC stands for Australian New Zealand Army Corps. Anzac parades are held in New Zealand and Australia on April 25, the day that the Anzac soldiers entered Anzac cove in Gallipoli in 1915.
} 
illustrations of Stefania's Slippers (Beck and Fisher) where some Polish language is visible on images of passports, and in The Red Poppy (Hill and Colston) in which a German soldier says "nein" and "Danke" and "hier."

Despite New Zealand being a very multilingual society (Davison), it is not surprising that most of the books mentioned solely use the English language, given its dominance in New Zealand society and the largely monolingual dominant culture. While cultural capital is often discussed as an essential aspect of culturally responsive pedagogy, the linguistic resources of children, or their linguistic capital is rarely accessed (Naqvi et al.).

The existence of four parallel texts in Mãori and English among the picturebooks nominated for the NZPBCII is a new departure for New Zealand picturebooks which have until lately been published as a separate English language and Māori language editions, but rarely published as parallel dual language books. The four books have presented the two languages in different ways. Kei te pēhea koe? How do you feel? (Duncan, Kei Te Pēhea Koe?) presents the text in Māori first and then in English underneath on each page, using the same font and size for both languages (see Daly, "Dual Language PictureBooks" for further analysis). The cover has the Māori title first with the English title underneath in smaller font. This order of languages, and the size of the font used, implies the importance of both languages, but the primacy of Māori, perhaps indicating the pedagogic intention of the book with regards to teaching te reo Māori (the Māori language).

In Ten Kooky Kiwis (Hinde et al.), the rhyme (based on Ten Green Bottles) is presented first in English, and then in Māori, with the English language version being presented across the first twenty-two pages, and the Māori version being presented across the last seven pages of the book in a smaller version of the same font used for the English language text. The order of the languages, and the space allocated to each both in terms of number of pages and size of font, imply the secondary status of te reo. No Māori language is evident on the cover of the book. The only indication on the cover of the book that Māori language is present in the book is that the translator, Te Okahurangi Tibble, is named.

Mōtiti Blue and the Oil Spill (McCauley and Waaka) uses a different strategy again for presenting the two languages (see Daly, "Dual Language PictureBooks" for further analysis). English and Māori are both presented on each page, with Māori underneath English and in italics of the same size and font. As this is a narrative non-fiction book, information panels are placed on each page giving extra factual information about different aspects of the story, and these are all in English. Māori words used as borrowings in these English information panels use macrons on long vowels. A very similar design is followed for Taratoa and the Code of Conduct (McCauley et al.), with English placed first on each page (or on 
right hand in double spreads) and Māori second (or on left hand in double spreads). In this book Mãori is in the same font and same size as English with no italics. Once again information panels are only presented in English with macrons on Māori borrowings and no Māori title is given to the book on the cover. While the use of macrons in Māori words, and the same font for both Māori and English in both books indicates knowledge of and respect for the Māori language (Daly, "Kūkupa, Koro and Kai"), the lack of a Māori title for the book, in addition to the placement of Mãori on each page, indicates a secondary status.

As a result, while the existence of these parallel text dual language picturebooks is a welcome new development in New Zealand picturebooks, perhaps reflective of a changing attitude to bilingualism, and the need for dual language books in New Zealand school settings, three of the four books present Māori in a lesser way, either by giving it less space, no Māori title, or by not representing all of the text in Māori. I suggest that such decisionmaking around order and placement of languages in these dual language books is not an indictment of individual publishers, authors, and designers, but perhaps a reflection of the sociolinguistic milieu in which the books are created.

\section{Conclusion}

In conclusion, the diversity present in New Zealand picturebooks nominated to be included in a collection reflecting New Zealand identity is somewhat mixed. In terms of ethnicity of characters, the largest proportion of books represented characters from several different ethnicities. This finding contrasts with findings from the Cooperative Children's Book Center. Judgements about the ethnicity of characters were made based on the text of the story and illustrations, but decisions were not always clear cut. Given that ethnicity is a self chosen label which does not always reflect appearances, and that often people identify with more than one ethnicity, analysis for this study was somewhat simplistic, based on setting, hair, eye and skin color, language use, and names.

With regard to the representations of families, there are more non-nuclear families (extended plus single parent plus blended) than nuclear families, and compared to some previous studies, there is some diversity presented. However, as with the previous study of the original NZPBC (Daly, "Family Composition as Depicted"), there are no families with same-sex parents, and so a lack of representation in this quarter, in line with Hardie's examinations of books in Wellington libraries.

As was found by Beckett et al., who examined the representation of children with disabilities in children's books for 5 to 11 year olds and 
concluded that there were still books using discriminatory language and negative stereotypes, people with disabilities are almost invisible in the 60 books nominated for the revised NZPBC. One book has a main character who is blind, and another a main character who is deaf, and three books centred around war show injured soldiers, but aside from this, even in background crowds people with disabilities are not represented which has implications for children with disabilities reading books in two ways. They will not see themselves to any great extent in the picturebooks they read, nor will their classmates have the opportunity to. A positive aspect to the analysis, however, is that as in some of the books analyzed by Beckett et al., children with disability who were represented in the picturebooks analyzed (Luke in Colour the Stars and Rewi Marama in Birds of Summer) were represented in a positive and authentic light.

Unlike disability, with regard to language, books nominated displayed a reasonable level of diversity, particularly with respect to use of borrowed words from Māori, but also other languages including Tongan, Cook Island Māori, Tokelauan, and Italian, German, Hindi, Samoan, Mandarin. Previous studies have shown that New Zealand English picturebooks do use a much higher rate of borrowed Māori words in their text than other kinds of texts analyzed, including newspapers and school journals (Daly, "Kūkupa, Koro and Kai"; "The Narrative Contract"; Macdonald and Daly). However, no previous studies have examined the use of words borrowed from other languages in New Zealand picturebooks, and this presents an area for future research.

The nomination of four parallel texts using both English and Māori within a single picturebook is another area that is relatively new. The way in which the two languages are presented in terms of order, font, italicization, and book title indicates the secondary status of te reo Māori in New Zealand and perhaps a level of tokenism (Harlow).

As discussed earlier, the power of children's literature collections is the access provided to books of a certain kind and character, and the affordances created with regard to supporting intercultural understanding (Cotton and Daly, "Visualising Cultures"; "Cross-Continental Readings"). In the case of New Zealand picturebooks that are often not reprinted and that form a small percentage of books available to New Zealand children, the New Zealand Picturebook Collection provides access to books that not only reflect New Zealand life and ways of using language, but that provide windows and mirrors (Bishop) into lives of a range of groups within New Zealand society (Daly, "Belonging and Differentiating"). The diversity evident in the books in this study show that some of the mirrors and some of the windows, particularly those relating to ethnicity, are relatively clean and transparent; but in relation to same-sex parented families and language diversity they are at best a bit foggy; and at worst (with regard to depicting people with disabilities) they are quite distorted. 
If we return to the notion of cultural hegemony, the critical lens (Botelho and Rudman) applied throughout the analysis for this article, examining who is present and who is absent, has indicated the continued hegemony across the dimensions of disability, same-sex parented families, and language use. Perhaps this supports the absolute necessity for children's literature collections featuring books which address these gaps, for example the extensive annotated list of books featuring disabled characters provided by Scope About Disabilities, and the Families Diversity Reading Resource created by Bishop Grosseteste University (Morris and Woolley), which in the absence of the ready availability of books reflecting diversity in these areas provide an equity of access for readers which is so desirable in truly equitable societies.

\section{References}

Alston, A. The Family in English Children's Literature. New York: Routledge, 2008. Print.

Beckett, A., et al.“Away with the Fairies?" Disability within Primary-Age Children's Literature. Disability \& Society, vol. 25, no. 3, 2010, pp. 373-86. doi:10.1080/09867591003701355. Print.

Bishop, R. S."Mirrors, Windows, and Sliding Glass Doors.” Perspectives, vol. 6, no. 3, 1990, pp. ix-xi. Print.

Blaska, J. K. Using Children's Literature to Learn about Disabilities and Illnesses. 2nd ed., Troy, NY: Educator's International Press, 2003. Print.

Botelho, M. J., and M. K. Rudman. Critical Multicultural Analysis of Children's Literature. New York: Routledge, 2009. Print.

Burke, C. L., et al.“Animals as People in Children's Literature.” Language Arts, vol. 81, no. 3, 2004, pp. 205-13. Print.

Cook, R. "New Zealand Families." Marriage \& Family Review, vol. 41, no. 3-4, 2007, pp. 24159. doi:10.1300/J002v41n03_02. Print.

Cooperative Children's Book Center. Children's Books by and about People of Color and First/Native Nations Published in the US 2002-2014. 2016. Web. 16 Feb. 2016. <https:// ccbc.education.wisc.edu/books/pcstats.asp $>$.

Cotton, P. Children's Picture Books Sans Frontières. London, UK: Trentham Books, 2000. Print.

Cotton, P., and N. Daly. "Visualising Cultures: The 'European Picture Book Collection' Moves 'Down Under.' " Children's Literature in Education, vol. 46, no. 1, 2015, pp. 88106. doi:10.1007/s10583-014-9228-9. Print.

Cotton, P., and N. Daly. "Cross-Continental Readings of Visual Narratives: An Analysis of Six Books in the New Zealand PictureBook Collection." Bookbird, vol. 53, no. 2, 2015, pp. 2645. doi:10.1353/bkb.2015.0036. Print.

Daly, N."Kūkupa, Koro and Kai: The Use of Māori Vocabulary Items in New Zealand English Picture Books." New Zealand English Journal, vol. 21, 2007, pp. 20-33. Print.

Daly, N.“The Narrative Contract and the Use of Māori Loanwords in New Zealand English Picture Books." Journal of Children's Literature Studies, vol. 5, no. 2, 2008, pp. 1-17. Print.

Daly, N. "Belonging and Differentiating: Aspects of New Zealand National Identity Reflected in the New Zealand Picture Book Collection (NZPBC)." Bookbird, vol. 51, no. 1, 2013, pp. 73-79. doi:10.1353/bkb.2013.0001. Print.

Daly, N. "Family Composition as Depicted in the New Zealand Picture Book Collection." Early Childhood Folio, vol. 19, no. 2, 2015, pp. 1-13. doi:10.18296/ecf.0012. Print. 
Daly, N. "Dual Language PictureBooks in Māori and English.” Bookbird, vol. 54, no. 3, 2016, pp. 10-17. doi:10.1353/bkb.2016.0092. Print.

Daly, N., and M. McKoy. "Picturebook Collections as Pedagogical Tools in Diverse Classrooms: The New Zealand Picture Book Collection (NZPBC) and the New Zealand Pacific Picture Book Collection (NZPPBC).” Literacy Forum NZ, vol. 28, no. 2, 2013, pp. 31-42. Print.

Davison, I. "NZ Sitting on Language Goldmine." New Zealand Herald, 5 Mar. 2013. Web. $<$ https://www.nzherald.co.nz/nz/news/article.cfm?c_id=1\&objectid=10869226>.

Friends of the Dorothy Neal White Collection (Friends of the DNWC). "Dorothy Neal White. A Tribute." Notes. Books. Authors, vol. 7, 1998. Print.

Hadaway, N., and T. A. Young. "Celebrating and Revitalising Language. Indigenous Bilingual Children's Books.” Bookbird, vol. 51, no. 3, 2013, pp. 56-67. doi:10.1353/bkb.2013.0062. Print.

Hardie, A. "Picture Books with Same-Sex Parented Families: Unintentional Censorship." The International Journal of Learner Diversities and Identities, vol. 20, 2014, pp. 45-52. ISSN\#2327-0128. doi:10.18848/2327-0128/CGP/v20i01/48559. Print.

Harlow, R. “Covert Attitudes to Māori.” International Journal of the Sociology of Language, vol. 172, 1995, pp. 133-47. Print.

International Children's Digital Library. "Library Fast Facts." 2015. Web. 5 Feb. 2016. <http:// en.childrenslibrary.org/about/fastfacts.shtml>.

International Children's Digital Library. "Mission.” 2015. Web. 15 Feb. 2016. <http://en. childrenslibrary.org/about/mission.shtml>.

Internationale Judenbibliotek. “About Us.” 2015. Web. 02 Feb. 2016. <http://www.ijb.de/en/ about-us.html>.

Johnson, D. The Joy of Children's Literature. Belmont, CA: Wadsworth Cengage Learning, 2012. Print.

Kelly, J. "Two Daddy Tigers and a Baby Tiger: Promoting Understandings about Same Gender Parented Families Using Picture Books.” Early Years, vol. 32, no. 3, 2012, pp. 288-300. doi:10.1080/09575146.2011.652074. Print.

Macdonald, D., and N. Daly. "Kiwi, Kapai, and Kuia: Māori Loanwords in New Zealand English Children's Picture Books Published between 1995 and 2005.” The Final Chapters: Concluding Papers of the Journal of Children's Literature Studies, edited by B. Carrington and P. Pinsent, Wizard's Tower Press, 2013, pp. 44-56. Print.

Morris, J., and R. Woolley. Family Diversity Reading Resource. Bishop Grosseteste University College Lincoln, 2008. Web. 23 Feb. 2016. <http://www.bishopg.ac.uk/research/projects/ Pages/past-projects.aspx>.

Naqvi, R., et al. "Dual-Language Books as an Emergent Literacy Resource: Culturally and Linguistically Responsive Teaching and Learning." Journal of Early Childhood Literacy, vol. 13, no. 4, 2013, pp. 501-28. doi:10.1177/1468798412442886. Print

Prater, M. A., et al. "Teaching Students about Learning Disabilities through Children's Literature." Intervention in School and Clinic, vol. 42, no. 1, 2006, pp. 14-24. doi:10.1177/10534512060420010301. Print.

Rieger, A., and E. McGrail. "Exploring Children's Literature with Authentic Representations of Disability." Kappa Delta Pi Record, vol. 51, no. 1, 2015, pp. 18-23. doi:10.1080/ 00228958.2015.988560. Print.

Scope About Disabilities. "List of Books Featuring Disabled Characters." 2016. Web. 23 Feb. 2016. <http://www.scope.org.uk/Support/Families/books/books-children/Old-list>.

Statistics New Zealand. “2013 Census Quickstats about Culture and Identity.” 2016. Web. 23 Feb. 2016. <http://www.stats.govt.nz/Census/2013-census/profile-and-summary-reports/ quickstats-culture-identity/languages.aspx $>$. 


\section{Books referred to from NZPBCII}

Beck, J., and R. Belton. The Christmas Caravan. Auckland: Scholastic, 2002. Print. Beck, J., and L. Fisher. Stefania's Dancing Slippers. Auckland: Scholastic, 2007. Print. Belcher, A., and D. Tipuna. The Girls in the Kapahaka. Auckland: Reed, 2006. Print. Belton, R. Herbert the Brave Sea Dog. Auckland: Craig Potton Publishing, 2008. Print. Cowley, J., and G. Bishop. The Little Tractor. Auckland: Scholastic, 2004. Print.

Drewery, M., and T. Duncan. Nanny Mihi's Garden. Auckland: Reed, 2001.Print.

Drewery, M., and B. Potter. Matariki. Auckland: Reed, 2003. Print.

Drewery, M., and C. White. Dad's Takeaways. Wellington: Mallinson Rendel, 2007. Print.

Duncan, T. Mere McKaskill's Boil-Up. Auckland: Reed, 2007. Print.

Duncan, T. Kei Te Pēhea Koe? How Do You Feel? North Shore, NZ: Puffin, 2008. Print.

Duncan, T., and B. Potter. Grandad's Medals. Auckland: Reed Publishing, 2005. Print.

Hill, D., and F. Colston. The Red Poppy. Auckland: Scholastic, 2012. Print.

Hinde, D., et al. Ten Kooky Kiwi. Auckland: Scholastic, 2014. Print.

Johnson, Sarah, and S. Tulloch. Wooden Arms. Auckland: Scholastic, 2012. Print.

Mahy, Margaret, and S. Kellogg. The Boy Who Was Followed Home. London: Dent, 1977. Print.

McCauley, D., et al. Taratoa and the Code of Conduct. Tauranga: Mauāo Press, 2014. Print.

McCauley, D., and T. Waaka. Mōtitī Blue and the Oil Spill. Tauranga: Māuao Press, 2015. Print.

McMillan, D., and K. White. Colour the Stars. Auckland: Scholastic, 2012. Print.

Mewburn, K., and R. Driscoll. Old Huhu. Manukau, Auckland: Scholastic, 2009. Print.

Moetaua, K., and B. Potter. Papa's Jandals. Rosedale: Scholastic, 2010. Print.

Morrison, Y., and D. Hinde. A Kiwi Night before Christmas. Auckland: Scholastic, 2003. Print.

Nelisi, L., and G. Hunter. Tane Steals the Show. Auckland: Scholastic, 1997. Print.

O'Rourke, M., and C. Pond Eyley. Lillibut's Te Araroa Adventure. Auckland: Duck Creek Press, 2014. Print.

Prebble, G., and S. Henderson. The Birds of Summer. Wellington: Reed, 1977. Print.

Sommerset, Mark, and Rowan Sommerset. Baa Baa Smart Sheep. Waiheke Island: Dreamboat Books, 2011. Print.

Sutton, Eve, and Lynley Dodd. My Cat Likes to Hide in Boxes. Wellington: Mallinson Rendel, 1973. Print. 